\title{
AN ECONOMETRICS ANALYSIS OF THE IMPACT EXCHANGE RATE ON ECONOMIC GROWTH OF NIGERIA
}

\author{
Okosu Napoleon David \\ Department of Economics, Veritas University, Abuja, FCT- Nigeria \\ Email: ndokosu@gmail.com
}

Cite this article:

Okosu Napoleon David (2021), An Econometrics Analysis of the Impact Exchange Rate on Economic Growth of Nigeria. African Journal of Economics and Sustainable Development 4(3), 185-198. DOI: 10.52589/AJESDEY7IWKD2.

\section{Manuscript History \\ Received: 27 Nov 2021 \\ Accepted: 21 Nov 2021 \\ Published: 30 Dec 2021}

Copyright $\odot 2020$ The Author(s). This is an Open Access article distributed under the terms of Creative Commons AttributionNonCommercial-NoDerivatives 4.0 International (CC BY-NC-ND 4.0 ), which permits anyone to share, use, reproduce and redistribute in any medium, provided the original author and source are credited.
ABSTRACT: The study interrogates the impact of exchange rate on the economic growth of Nigeria from 1981 to 2020 using quarterly time-series data from the Central Bank of Nigeria and the World Bank National Account. The dependent variable in the model was Real Gross Domestic Product (RGDP), and the independent variables were Exchange Rate (EXCHR), inflation (INFL), Interest Rate (INTR), Foreign Direct Investment (FDI), Broad Money Supply (M2) and Current Account Balance of Payment (CAB). The methodology employed was the AutoRegressive Distributed Lag (ARDL) model which incorporates the Cointegration Bond test and Error-Correction Mechanism. The finding indicates that in the short run, EXCHR, CAB, M2 and FDI, had a positive impact on economic growth. The impact of EXCHR and $C A B$ were significant on growth while that of M2 and FDI were insignificant to growth. However, INTR and INFL had a negative impact on economic growth with both variables being statistically significant. The bound test showed that there was a long-run relationship among the study variables, and the results from the long run reveal that the exchange rate has a positive and significant impact on economic growth. Inflation, Interest rate, FDI, Current Account Balance of Payment (CAB) and Broad Money Supply all have a positive and significant impact on economic growth. Based on the findings the study recommended that monetary authority should strictly monitor the operations of banks and other forex dealers with a view of ensuring unethical practices are adequately sanctioned to serve as a deterrent to others.

KEYWORDS: Econometrics Analysis, Exchange Rate, Economic Growth, Real Gross Domestic Product, Nigeria 


\section{INTRODUCTION}

Exchange rate is the value at which one unit of a country's currency exchanges with another country's currency. It can also be seen as the price of a unit of a nation's currency in relation to another nation's currency. Hence, the exchange rate is a conversion factor, a ratio, or a multiplier depending on the direction of conversion. In modern times, most nations do not practice autarchy, as they are involved in trade and other transactions between them and other countries. In dealing with other countries, the exchange rate plays a fundamental role. It performs a cardinal role in international trade and macroeconomic variables that are used in defining global competitiveness. In this era of globalization, the importance of exchange rate is very vital to an economy. The movement of the exchange rate has corresponded impact on many macroeconomic variables such as inflation, interest rate, Gross Domestic Product (GDP), Foreign Direct Investment (FDI), import and export, etc. The impact on these variables highlights the importance of exchange rate in an economy that trade with the outside world

The Nigerian economy has experienced a major transformation in its exchange rate policy. From independence in 1960 to 1967, there was fixed parity between the Nigerian pound and the British pound, from 1967 to 1974 it was fixed parity between the Nigerian pound and the American dollar, it is important to note that in 1973, the local currency, the Nigerian Pound was changed to the Nigerian Naira. From 1974 to 1976, the Naira (Nigeria's local currency) was tied to an import-weighted basket of currencies, whereas from 1976 to 1985, it was pegged to an independent exchange rate mechanism 2016 (Okorontah and Odoemena). However, following the economy's near-collapse between 1982 and 1985 (Akpan and Atan 2012), the government established a market-determined exchange rate policy in 1986, a sequel to the adoption of a Structural Adjustment Programme (SAP).

Following the implementation of SAP, a new foreign exchange market, the Second-tier Foreign Exchange Market (SFEM), was established on September 26, 1986. In 1995 and 1999, the Autonomous Foreign Exchange Market (AFEM) and the Inter-bank Foreign Exchange Market (IFEM) were formed. On October 25, 1999, the AFEM became the IFEM, a daily two-way quote market. CBN replaced IFEM with the Dutch Auction System (DAS) on July 16, 2002, and it has been in operation since then. Despite these efforts, the Nigerian naira continues to devalue against major currencies, badly impacting the economy (Okoro and Charles, 2019).

The exchange rate did experience more volatility after the adoption of SAP due to excessive exposure to external shocks. The effect of the global financial crisis, as well as the current COVID-19 Pandemic, has a tremendous effect on the exchange rate. Naira exchange rate to the dollar rose astronomically from about N120/\$ to about N180/\$ (about 50\% increase) between 2008 and 2009. This is attributed to the sharp drop in foreign earnings of Nigeria as a result of the persistent fall of crude oil price, which plunged from an all-time high of US\$147 per barrel in July 2007 to a low of US\$45 per barrel in December 2008 (CBN, 2008), while in the COVID 19 pandemic era, the rate depreciated by 24\% (from January 30 2020, when World Health Organization declared the novel coronavirus outbreak a public health emergency of international concern to January 2021). In raw figures, it moved from N306.5 to 1USD $\$$ on $31 / 01 / 2020$ to N410.89 to 1 USD $\$$ on 30/09/2021 (CBN, 2021).

The remaining part of the paper would be structured as follows: section one deals with the introduction, this section has other subsections of the statement of the problem, objectives of the study and hypothesis. The next is Section two, which entails the review of related literature 
and theoretical framework. Section three presents the research methodology and specification, while section four will settle for data analysis and discussion of results. Lastly, section five, concludes and proffer policy recommendations

\section{Objectives of the study}

The principal objective of this research paper is to empirically investigate the impact of the exchange rates on the economic growth of Nigeria.

This study will enhance policymaking by the government and other agencies saddled with the responsibility of dealing with foreign exchange in Nigeria. It would add value to the available literature on the relationship between exchange and growth rates in the Nigerian economy. The uniqueness of the study can be observed from the variables used for the analysis. Several studies have been conducted on a similar topic; however, the variables chosen in this study are different from most of the other studies in Nigeria.

\section{THEORETICAL FRAMEWORK AND LITERATURE REVIEW}

\section{Theoretical Framework}

There are many theories in respect of exchange rate, however, for the purpose of this paper, purchasing power parity theory is considered. The purchasing power parity theory was developed by Guster Cassel in 1981. In an effort to retort to call for a substitute exchange rate determination system following the fall of the fixed exchange rate system, the purchasing power parity theory was advanced. The theory which is also called the inflation theory of exchange rates states that the exchange rate between two currencies is solely determined by the movement of demand and supply forces. The basis of the theory is that, if any pair of currency is set at par, then, the exchange rate differential should reflect variations arising from the purchasing powers of the relative currency in relation to the Base Exchange rates (Ibenta, 2012). According to (Obadan, 2006), the Theory suggests that the difference in inflation rates between countries will affect the spot exchange rate between currencies. As a result, the buying power equality of two inconvertible paper currencies determines the equilibrium exchange rate. That is, the relative price levels of two countries determine the exchange rate between them. The purchasing power parity hypothesis has been updated over time and is now widely used by international financial market participants to determine the exchange rate between two currencies. (Anyanwu et al. 2017)

\section{Literature Review}

Shaik and Gona (2020) examined the impact of the exchange rates on economic growth in India. From 1990 to 2017, the researchers employed the standard least square and VECM Granger Causality methods of estimation. The study concludes that the extent of the exchange rate and its determinants determine the degree of growth rate in India. They advised that all sectors of the Indian economy be technologically oriented and that excessive budgetary deficit should be reduced to the barest minimum in order to avoid the ideal of foreign borrowing, which would inevitably result in external debt and services. 
Kenny (2019) examined exchange rate fluctuation during the different exchange rate regimes in Nigeria, investigating exchange rate impact on economic growth rate to determine which of the exchange rate regime significantly influence economic growth in Nigeria covering periods from 1981 to 2015. The Fully Modified Ordinary Least Square (FMOLS) estimate approach and diagnostic tests were used in the data analysis process. The FMOLS findings revealed that the currency rate, foreign reserve, money supply, and capital input all have a major impact on Nigeria's economic growth, however, labour has no such impact in the long run. Furthermore, the dummy variable shows a negative insignificant coefficient, implying that a fixed exchange rate will not benefit Nigeria's economy in the long run. This study suggests that the country's continued use of a manageable floating exchange rate regime will greatly stimulate domestic production, resulting in a rise in Nigeria's external reserve pool.

In South Africa, Patel and Mah (2018) looked into the relationship between the real exchange rate and economic growth. Long-run results demonstrated a negative and significant link between real exchange rate and export and economic growth. Money supply and foreign direct investment, on the other hand, have a positive and considerable link with the real exchange rate. In the short run, only export was important and positively related to the real exchange rate. The results of variance decomposition revealed that economic growth shocks had a significant impact on the real exchange rate. The impulse response functions revealed that real exchange rate and money supply shocks had a favourable effect on real exchange rates. Exports, money supply, foreign direct investment, and economic growth must all be increased because this will result in a rise in the Rand and, as a result, an appreciation of the Rand.

Okorontah and Odoemena (2016) studied the impact of exchange rate fluctuations on Nigerian economic growth. The study examined the relationship between exchange rate and economic growth using annual data from 1986 to 2012. It used the ordinary least square (OLS) technique, the Johansson co-integration test, and the error correction mechanism (ECM). The findings imply that in Nigeria, there is no strong link between the exchange rate and economic growth. It is, therefore, suggested that Nigeria improve its competitive capacity in the international market through export diversification.

Amassoma and Odeniyi (2016) examined the relationship between exchange rate volatility and economic growth in Nigeria, focusing on the ordinary Nigerian's purchasing power and the level of international transaction. The findings of this study revealed that exchange rate fluctuations had a beneficial but minor impact on Nigerian economic growth in the long and short run. It recommended that government should encourage domestic production of goods and services for Naira exchange rate appreciation and generally to promote economic growth in Nigeria. Also, the government should set its eyes on some highly volatile macroeconomic variables for example Nigeria's inflation rate and global oil price.

On the basis of annual data from 1980 to 2012, Ugochukwu (2015) examined the impact of currency rate volatility on Nigerian economic development. The relationship between exchange rate volatility and economic growth was calculated using the Generalized Autoregressive Conditional Heteroscedasticity $(\mathrm{GARCH})$ technique to produce exchange rate volatility. The findings also revealed that in the short run, economic growth in Nigeria is negatively responsive to exchange rate volatility, while in the long run, the two variables in the Nigerian economy have a negative association. To protect against the vicissitudes of exchange rate volatility, the study recommends controlling the import content of both public and private 
expenditure, as well as greater economic diversification through investment in key productive sectors.

The relationship between exchange rate, interest rate, and economic growth was experimentally examined by Obansa et al. (2013) in their study of the nexus of three macroeconomic variables in the Nigerian economy using data from 1970 to 2010. The Impulse Response component and the Forecast Error Variance Decomposition were used in the analysis using the vector autoregression (VAR) technique. The impact of the deregulated and regulated eras on the Nigerian economy was also split in the study. The findings revealed that the exchange rate had a higher impact on economic growth than the interest rate. It was decided that exchange rate liberalization is beneficial to the economy since it fosters economic growth. However, interest rate liberalization has little impact on economic growth because it dampens investment motivation.

In their investigation of the impact of exchange rate variations on real output growth in Nigeria, Akpan and Atan (2012) used quarterly data from 1986 to 2010 to examine the possible direct and indirect nexus between exchange rates and GDP growth in Nigeria. According to the data, there is no strong direct link between exchange rate movements and output growth. The study concluded that better exchange rate management is vital but insufficient to revive the Nigerian economy and that a comprehensive economic reform program is required to supplement the current exchange rate strategy.

\section{METHODOLOGY}

The econometrics methodology espoused in this paper is the ARDL co-integration Bound test. Quarterly time series data from 1981 to 2020 were adopted. The data were obtained from World Bank National Account data and CBN statistical bulletin. For the stationarity test, the Augmented Dickey-Fuller (ADF) Unit Root Test was handy. The research further estimated the Error Correction Model to verify the speed of adjustment of the parameters back to their equilibrium path if they deviate from their equilibrium path. Finally, post estimation diagnostic test of Lagrange multiplier test of residual serial correlation, Breusch-Godfrey heteroscedasticity test, Ramsey's RESET test and Jarque Bera test, Cusum test and Cusum of Square test were performed.

\section{Model Specification}

To accomplish the prime objective of this paper, a linear regression model was prepared for the conduct of the analysis. Real Gross Domestic Product (RGDP) was used in place of GDP to accommodate the concerns of inflation. We present the model as thus:

RGDP=f (EXCHR, INTR, INFL, M2, FDI, and CAB)....

The above was transmogrified into an econometric model, we then have:

$\mathrm{GDP}=\mathrm{b} 0+\mathrm{b} 1 \mathrm{EXCHR}+\mathrm{b} 2 \mathrm{INT}+\mathrm{b} 3 \mathrm{INFL}+\mathrm{b} 4 \mathrm{BDM}+\mathrm{b} 5 \mathrm{FDI}+\mathrm{b} 6 \mathrm{CAB}+\mathrm{Ut}$. 
Theoretically, the signs of the coefficients above are expected to be:

b1 $<0, \mathrm{~b} 1>0, \mathrm{~b} 2>0, \mathrm{~b} 3>0, \mathrm{~b} 4>0, \mathrm{~b} 5>0, \mathrm{~b} 6>0$.

Where: RGDP $=$ Real Gross Domestic Product; EXCHR = Exchange Rate; INTR=Interest Rate $\mathrm{INFL}=$ Inflation; BDM =BROAD Money $(\mathrm{M} 2) ; \mathrm{FDI}=$ Foreign Direct Investment $\mathrm{CAB}=$ Current Account of Balance of Payment

bo represents the constant; b1- b6 represents the coefficients of the regressor variables.

$\mathrm{Ut}=$ Error term

\section{ARDL Cointegration Approach}

The ARDL representation of equation 3.2 can be presented as thus;

$$
\begin{aligned}
\Delta R G D P_{t}=\alpha_{0} & +\sum_{i=1}^{n} \alpha_{1 i} \Delta E X C H R_{t-i}+\sum_{i=1}^{n} \alpha_{2 i} \Delta I N T R_{t-i}+\sum_{i=1}^{n} \alpha_{3 i} \Delta I N F L_{t-i} \\
& +\sum_{i=1}^{n} \alpha_{4 i} \Delta M 2_{t-i}+\sum_{i=1}^{n} \alpha_{5 i} \Delta F D I_{t-i}+\sum_{i=1}^{n} \alpha_{6 i} \Delta C A B_{t-i}+\beta_{1} R G D P_{t-1} \\
& +\beta_{2} E X C H R_{t-1}+\beta_{3} I N T R_{t-1}+\beta_{4} I N F L_{t-1}+\beta_{5} M 2_{t-1}+\beta_{6} F D I_{t-1} \\
& +\beta_{7} C A B_{t-1}+\mu_{t}
\end{aligned}
$$

Where; $\Delta$ is the first-difference operator, and $\beta$ 's shows the long-run coefficients and short-run coefficients. Hence, the null hypothesis $\left(\mathrm{H}_{0}\right)$ of no cointegration states that, $\mathrm{H}_{0}: \beta_{1}=\beta_{2}=\beta_{3}=$ $\beta_{4}=\beta_{5}=\beta_{6}=\beta_{7}=\beta_{7}=0$ and the alternative hypothesis of existence of co-integration state that; $\beta_{1} \neq \beta_{2} \neq \beta_{3} \neq \beta_{4} \neq \beta_{5} \neq \beta_{6} \neq \beta_{7} \neq \beta_{7} \neq 0$.

\section{ARDL error-correction model (ARDL-ECM) approach}

The short-run causality model from the ARDL model is presented in equation 3.4;

$$
\begin{aligned}
\Delta R G D P_{t}=\alpha_{0} & +\sum_{i=1}^{n} \alpha_{1 i} \Delta E X C H R_{t-i}+\sum_{i=1}^{n} \alpha_{2 i} \Delta I N T R_{t-i}+\sum_{i=1}^{n} \alpha_{3 i} \Delta I N F L_{t-i} \\
& +\sum_{i=1}^{n} \alpha_{4 i} \Delta M 2_{t-i}+\sum_{i=1}^{n} \alpha_{5 i} \Delta F D I_{t-i}+\sum_{i=1}^{n} \alpha_{6 i} \Delta C A B_{t-i}+\mu_{t}
\end{aligned}
$$

Where, $\Delta$ is the difference operator, ECM represent the Error Correction Term (ECT) derived from the long-run co-integrating relation from specified ARDL models equation 3.3. In equation 3.4, $\rho$ should exhibit a negative and significant sign for causality to exist in the long run. 
African Journal of Economics and Sustainable Development

ISSN: 2689-5080

Volume 4, Issue 3, 2021 (pp. 185-198)

www.abjournals.org

\section{DATA ANALYSIS AND INTERPRETATION OF RESULT}

Table 4.1: Descriptive Analysis Result

\begin{tabular}{|l|l|l|l|l|l|l|l|}
\hline & RGDP & M2 & INTR & FDI & INFL & CAB & EXCHR \\
\hline Mean & 35779.59 & 7960.698 & 13.07624 & 401901.5 & 19.53065 & 753794.1 & 100.7495 \\
\hline Median & 24478.18 & 1175.974 & 13.27480 & 124192.9 & 12.92100 & 94453.83 & 107.0243 \\
\hline Maximum & 78232.53 & 42506.09 & 26.00000 & 1360308. & 76.75887 & 4891744. & 353.8859 \\
\hline Minimum & 13779.49 & 16.16170 & 6.000000 & 264.3000 & 0.223606 & -5215524. & 0.610025 \\
\hline Std. Dev. & 21129.79 & 11779.57 & 3.994451 & 447875.8 & 17.85831 & 1831945. & 100.4389 \\
\hline Skewness & 0.647217 & 1.428138 & 0.678334 & 0.677322 & 1.727701 & -0.269436 & 0.872835 \\
\hline Kurtosis & 1.864049 & 3.876166 & 4.443873 & 1.933045 & 5.067997 & 5.162376 & 2.945304 \\
\hline $\begin{array}{l}\text { Jarque- } \\
\text { Bera }\end{array}$ & 4.943237 & 14.87664 & 6.542197 & 4.955752 & 27.02736 & 8.277087 & 5.083931 \\
\hline Probability & 0.084448 & 0.000588 & 0.037965 & 0.083921 & 0.000001 & 0.015946 & 0.078712 \\
\hline & & & & & & & \\
\hline Sum & 1431184. & 318427.9 & 523.0496 & 16076059 & 781.2261 & 30151765 & 4029.979 \\
\hline $\begin{array}{l}\text { Sum Sq. } \\
\text { Dev. }\end{array}$ & $1.74 \mathrm{E}+10$ & $5.41 \mathrm{E}+09$ & 622.2700 & $7.82 \mathrm{E}+12$ & 12437.84 & $1.31 \mathrm{E}+14$ & 393430.8 \\
\hline $\begin{array}{l}\text { Observa- } \\
\text { tons }\end{array}$ & 40 & 40 & 40 & 40 & 40 & 40 & 40 \\
\hline
\end{tabular}

Source: Author's Computation from E-Views 11, 2021.

Table 4.1 shows the descriptive statistics of RGDP, EXCHR, M2, INTR, FDI, INFL and CAB. It can be shown that the variables contained 40 observations with $C A B$ having the highest mean value followed by FDI, RGDP, MS INFL and INTR respectively. The table also revealed that only CAB is negatively skewed to the left. The RGDP and FDI are platykurtic as the value of their kurtosis are less than three, while MS, INTR, INFL and CAB are mesokurtic in nature as the value of their kurtosis are greater than three. The probability of the Jarque-Bera shows that EXCHR, FDI and RGDP are normally distributed while M2, INTR, INFL and CAB were not normally distributed.

\section{Unit Root Test}

The Augmented Dickey-Fuller test will be used to test for unit root. All the variables were regressed on-trend and intercept to determine if they have a trend, it was discovered that the five variables have trend and intercept, hence the unit root test involves trend and intercept. The result is presented:

Table 4.2: Unit Root Stationarity Result

\begin{tabular}{|l|l|l|l|}
\hline Variable & ADF Statistics & Prob. & Stationary Status \\
\hline RGDP & -3.6515 & 0.0091 & $\mathrm{I}(1)$ \\
\hline CAP & -3.6641 & 0.0087 & $\mathrm{I}(0)$ \\
\hline FDI & -8.1625 & 0.0000 & $\mathrm{I}(1)$ \\
\hline INFL & -3.2128 & 0.0234 & $\mathrm{I}(0)$ \\
\hline INTR & -3.2685 & 0.0234 & $\mathrm{I}(0)$ \\
\hline
\end{tabular}


African Journal of Economics and Sustainable Development

ISSN: $2689-5080$

Volume 4, Issue 3, 2021 (pp. 185-198)

www.abjournals.org

\begin{tabular}{|l|l|l|l|}
\hline $\mathrm{M} 2$ & -5.1246 & 0.0001 & $\mathrm{I}(1)$ \\
\hline EXCH & -3.4580 & 0.0022 & $1(1)$ \\
\hline
\end{tabular}

The critical values for rejection of hypothesis of unit root were from MacKinnon (1996) as reported in e-views 11.0.

Source: Author's Computation from E-Views 11, 2021.

Table 4.2 depicts the unit root test result using the ADF unit root test, the table revealed that CAP, INFL and INTR are stationary at the level and are said to be integrated of order zero I(0) making it necessary for other variables to be differenced. At first difference, RGDP, FDI and M2 became stationary and they are said to be integrated of order one I(1). Hence, given the mixture of the level of integration of the variables, we adopt the autoregressive distributive lag (ARDL) bounds testing approach developed by Pesaran et al. (2001) to test whether the longrun relationship exists between the variables.

\section{Empirical Analysis and Interpretation}

\section{ARDL Bound Test Approach to Cointegration}

The bound test approach to cointegration seeks to confirm if there is a long-run relationship among the variables in the model. This is done by testing if their coefficients are equal to zero in our estimated model or not. The F-Statistic value from the bound test and the critical value bounds as revealed by the regression result using E-views 11 is presented in table 4.3;

Table 4.3: ARDL Bounds Test Result

\begin{tabular}{|c|c|c|}
\hline \multicolumn{3}{|c|}{ Null Hypothesis: No long-run relationships exist } \\
\hline Test Statistic & Value & $\mathrm{K}$ \\
\hline F-statistic & 6.608337 & 6 \\
\hline \multicolumn{3}{|c|}{ Critical Value Bounds } \\
\hline Significance & I0 Bound & I1 Bound \\
\hline $10 \%$ & 2.26 & 3.35 \\
\hline $5 \%$ & 2.62 & 3.79 \\
\hline $2.5 \%$ & 2.96 & 4.18 \\
\hline $1 \%$ & 3.41 & 4.68 \\
\hline
\end{tabular}

Author's computation from E-Views 11, 2021. 
The result presented in table 4.4 suggests that the sign of the coefficient associated with each variable do not differ in the long and in the short run. The result indicated that a unit increase in Money supply (M2) will lead to a 0.118112 increase in real GDP in the short run. A unit increase in INTR will lead to a 134.888525 decrease in real GDP in the short run. This result is significant as indicated by the probability value of 0.0169. A unit increase in FDI will lead to a 0.000217 increase in RGDP in the short run. Also, a unit increase in INFL will lead to a 28.114251 decrease in RGDP in the short run with the result being statistically significant. A unit increase in the exchange rate (depreciation) will lead to a 48.16888 unit increase in RGDP with the result being statistically significant. Finally, a unit increase in CAB will lead to a 0.000279 increase in RGDP in the short-run with the result statistically significant.

Also, the outcome of this result tested using some diagnostic tests such Breusch-Godfrey Serial Correlation LM Test, Ramsey's RESET test, Normality Test and Heteroscedasticity test is not different from what is recorded in the long run estimation. The result of these tests is presented in Table 4.5 shows that the model passes all the diagnostic tests. The diagnostic tests applied to the model point out that there is no evidence of serial correlation, heteroscedasticity, the RESET test implies the correctly specified ARDL model and the result of the normality test showed that the residuals are normally distributed.

The estimated coefficient of the error correction term is highly significant, thus confirming the previous results that there is a long-run relationship between the variables. Furthermore, the magnitude of the estimated coefficient of the error correction term suggests a relatively high speed of adjustment to any disequilibrium in the short run. In other words, the estimated ECT1 is equal to 0.437 which states that the departure from the equilibrium is adjusted by $43.7 \%$ per year.

\section{Estimated ARDL Long-run Model}

Table 4.5: ARDL Long-run Result

\begin{tabular}{|l|l|l|l|l|}
\hline Long Run Coefficients & & & & \\
\hline & & & & \\
\hline Variable & Coefficient & Std. Error & t-Statistic & Prob. \\
\hline & & & & \\
\hline M2 & 1.085370 & 0.099106 & 10.951593 & 0.0000 \\
\hline INTR & 796.332749 & 146.081572 & 5.451288 & 0.0001 \\
\hline FDI & 0.021121 & 0.002858 & 7.388835 & 0.0000 \\
\hline INFL & 186.796088 & 35.233968 & 5.301591 & 0.0001 \\
\hline CAB & 0.000639 & 0.000285 & 2.240206 & 0.0396 \\
\hline EXCHR & 359.279123 & 129.434856 & 2.775752 & 0.0322 \\
\hline C & 13043.086396 & 2150.041710 & 6.066434 & 0.0000 \\
\hline Author's computation from
\end{tabular}

Author's computation from E-Views 11, 2021. 
From Table 4.6, a unit increase in M2 on average will lead to a 1.085370 increase in RGDP holding other variables constant. A unit increase in INTR on average will lead to a 796.332749 increase in RGDP holding other variables constant. A unit increase in FDI on average will lead to a 0.021121 increase in RGDP holding other variables constant. A unit increase in the exchange rate will lead to a 359.279123 increase in RGDP. Furthermore, a unit increase in INFL and CAB will lead to an increase in RGDP by 186.796088 and 0.000639 respectively. All the independent variables are statistically significant at a 5 percent level of significance as indicated by their low probability values.

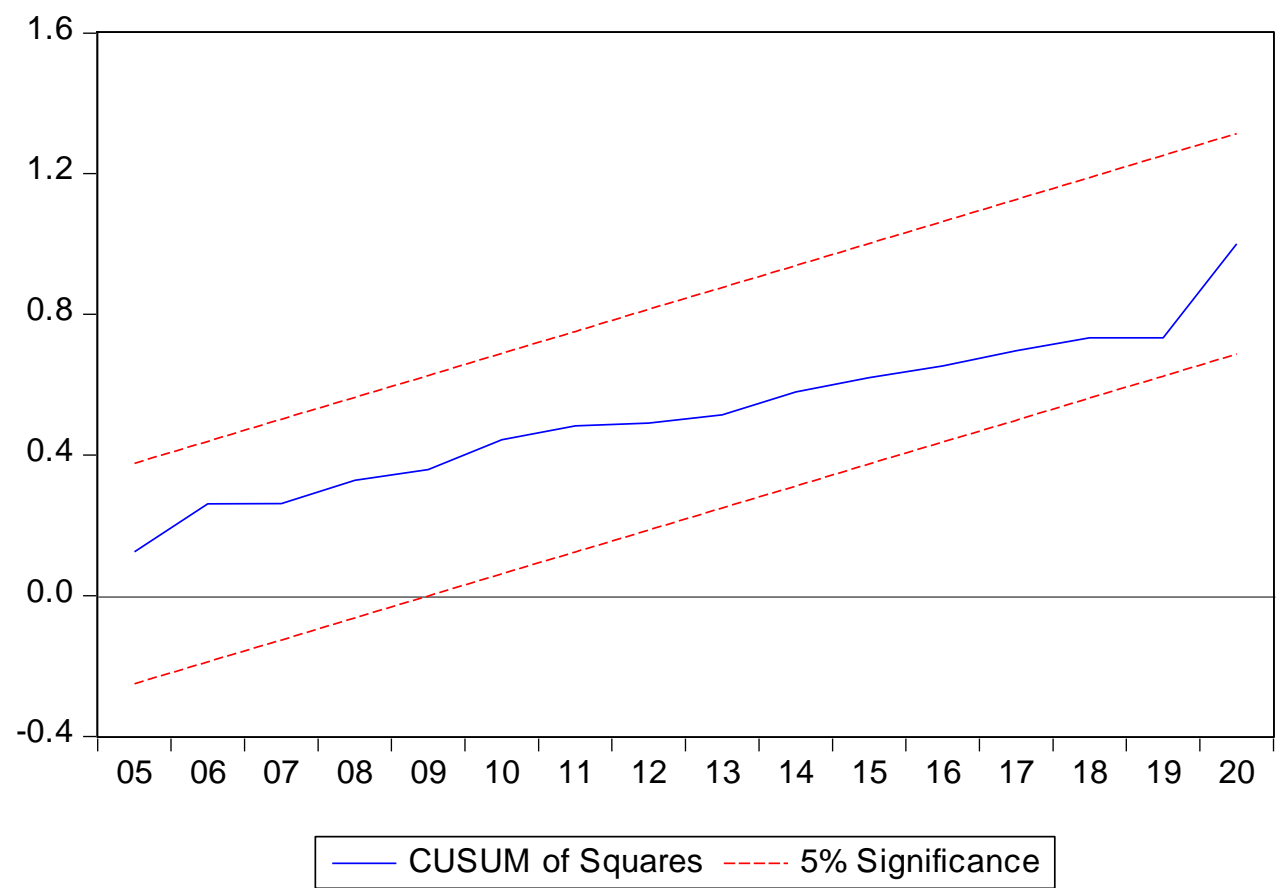

Figure 1: Stability (CUSUM of Squares) Tests

The stability of the regression coefficients is tested using the CUSUM of Squares of the recursive residual test for structural stability. Plots of the CUSUM of Square show that the regression equation seems stable given that the CUSUM of Squares tests statistics did not exceed the $5 \%$ level of significance boundary.

\section{CONCLUSION AND RECOMMENDATION}

\section{Conclusion}

The study investigated the impact of the exchange rate on the economic growth of Nigeria from 1981 to 2020 using quarterly time-series data from the Central Bank of Nigeria and the World Bank National Account data. The dependent variable in the model was economic growth proxied by Real Gross Domestic Product (RGDP), and the independent variables were exchange rate, inflation, interest rate, Foreign Direct Investment (FDI), Broad Money Supply 
(M2) and Current Account Balance of Payment (CAB). The study conducted a stationarity test and the result indicated that the variables were stationary at different orders of integration. The methodology employed was the Auto-Regressive Distributed Lag (ARDL) model which incorporates the Cointegration Bond test and Error-Correction Mechanism. The finding indicates that in the short run, Exchange rate, CAB, M2 and FDI, had a positive impact on economic growth. The impact of Exchange rate and $\mathrm{CAB}$ were significant on growth while that of M2 and FDI were insignificant to growth. However, interest rate and Inflation had a negative impact on economic growth with both variables being statistically significant.

The bound test showed that there was a long-run relationship among the study variables, and the results from the long run reveal that the exchange rate has a positive and significant impact on economic growth. This result is in-line with the study of Uddin et al. (2014); Shaik and Gona (2020); Nwafor (2018); Okorontah and Odoemena (2016); Okoro and Charles (2019) who all observed a positive and significant impact of exchange rate on economic growth. However, some studies such as Patel and Mah (2018; Amassoma and Odeniyi (2016) had contrary views.

Inflation, Interest rate and Broad Money Supply also have a positive and significant impact on economic growth, the findings are in tandem with the study of Kenny (2019). Furthermore, FDI and Current Account Balance of Payment (CAB) have positive and significant impacts on economic growth.

Some post diagnostic test was carried out to confirm if the model is stable and free from heteroskedasticity, autocorrelation, etc. The results revealed that the model was stable, homoskedasticity existed and no serial correlation. Also, both CUSUM and CUSUMQ tests indicated that they lie within the critical bounds.

\section{RECOMMENDATION}

Consequent to the above findings, the following recommendations are hereby suggested:

i. Government should make efforts to stop the importation of refined petroleum products as it puts huge strains on the exchange rate.

ii. The monetary authority should strictly monitor the operations of banks and other forex dealers with a view of ensuring unethical practices are adequately sanctioned to serve as a deterrent to others.

iii. Government should pursue export-oriented strategies that would engender more export that would earn more foreign exchange. The issue of standardization of our export produce should be taken seriously to meet international standards. 


\section{REFERENCES}

Abraham, T.W. (2016). Exchange Rate Policy and Falling Crude oil Prices: Effect on the Nigerian Stock Market CBN Journal of Applied Statistics Vol. 7 No. 1(a) (June, 2016)

Akpan, E. O. \& Atan, A. J. (2012). Effects of exchange rate movements on economic growth in Nigeria. CBN Journal of Applied Statistics, 2(2): 1-14.

Amassoma, D., and Odeniyi, B. D. (2016). The Nexus Between Exchange Rate Variation and Economic. Singaporean Journal of Business Economics, and Management Studies, Vol.4, No. 12, Pp. 7-28.

Anyanwu, F. A., Ananwude, A. C., \& Okoye, N.T. (2017). Exchange Rate Policy and Nigeria's Economic Growth: A Granger Causality Impact Assessment. International Journal of Applied Economics, Finance and Accounting Vol.1, No. 1, pp. 1-13 Ayodele, T. D. (2014). An Empirical Evaluation of the Impact of Exchange Rate on the Nigeria Economy. Journal of Economics and Sustainable Development, 24-29.

Central Bank of Nigeria (CBN; 2008), Annual report and statement of account; Abuja, Nigeria 2021 Central Bank of Nigeria $\mid$ Exchange Rate (cbn.gov.ng)

Central Bank of Nigeria. (2017). Statistical Bulletin.

Dickey, D.A., \& Fuller, W.A. (1979). Distribution of the estimators for autoregressive time series with a unit root. Journal of the American Statistical Association, 74(1), 427-431.

Engle, R.F. \& Granger, C.W.J. (1987). Cointegration and Error Correction Representation: Estimation and Testing. Econometrica, 55(2): 251-276.

Granger, C. W. J., (1998). Causality, cointegration and control. Journal of Economic Dynamics and Control, 12(2-3): 551-559.

Ibenta, S. N. O. (2012). International Trade and Finance, Ezu Book Ltd, Enugu.

Jhingan M. L. (2004): Money, Banking, International Trade and Public Finance, New Delhi: Vrinda Publications Ltd.

Johansen, S. and Juselius, K.(1990). Maximum likelihood estimation and inference on cointegration - with applications to the demand for money. Oxford Bulletin of Economics and Statistics, 52(2): 169-210.

Joshua, S. R., Happy, D. G. and Dankumo, A. M. (2016). Growth of non-oil sectors: A key to diversification and economic performance in Nigeria. Public Policy and Administration Research, 6(3), 64-75. Available at: https://tinyurl.com/qmnqyo4

Kenny, V. S. (2019). Exchange Rate Management and Economic Growth: An FMOLS Approach. https://mpra.ub.uni-muenchen.de/93125/ MPRA Paper No. 93125, posted 08 Apr 2019 03:54 UTC

MacKinnon, J.G. (1996). Numerical Distribution Functions for Unit Root and Cointegration Tests. Journal of Applied Econometrics, 11(6): 601-618

Narayan, P. K., (2005). The saving and investment nexus for China: Evidence from cointegration tests. Applied Economics, 37(17): 1979-1990.

Nwafor, M. C. (2018). Effect of Naira Rate on Economic Growth in Nigeria IIARD International Journal of Banking and Finance Research ISSN 2695-186X Vol. 4 No. 1 2018 www.iiardpub.org

Obadan M. (2006) Overview of Exchange rate Management in Nigeria from 1986 to 2006. Bullion Publication of CBN, July - September, Vol. 30, No 3, pp 1-9.

Obansa, S. A. J., Okoroafor, O. K. D., Aluko, O. O. \& Eze, M. (2013) Perceived relationship between exchange rate, interest rate and economic growth in Nigeria: 1970 - 2010, American Journal of Humanities and Social Sciences, 1(3), 116-124 
Okoro, C.U. \& Charles, F. B (2019). Naira Exchange Rate Variation and Nigeria Economic Growth: A Time Series Stud\& Social Review. 5 (2), 21-31

Okorontah, C. F. \& Odoemena, I. U. (2016) Effect of exchange rate fluctuation on the economic growth of Nigeria, International Journal of Innovative Finance and Economic Research, 4(2), 1-7.

Patel, D. \& Mah, G (2018). Relationship between Real Exchange Rate and Economic Growth: the case of South Africa Journal of Economics and Behavioral Studies Vol. 10, No. 1, pp. 146-158.

Pesaran, M. H., Shin, Y. and Smith, R. J. (2001). Bounds testing approaches to the analysis of level relationships. Journal of Applied Econometrics, 16(3): 289-326.

Shaik, K. \& Gona B. R (2020). Exchange rate and the economic growth in India: An empirical analysis. J Public Affairs. 2020; e2177

Uddin, K. M. K., Rahman, M. M. \& Quaosar, G. M. A. A. (2014). Causality between Exchange Rate and Economic Growth in Bangladesh. European Scientific Journal, 10(31): 11-26

Ugochukwu P.U. (2015) Nigeria Exchange Rate Volatility and Economic Growth in Nigeria. Journal of Economics Vol. 3 | No. 3 August | 2015 ISSN 23478233 